Jurnal IImiah Pendidikan Matematika Volume 8 No. 3 Tahun 2019

ISSN :2301-9085

\title{
Profil Antisipasi Siswa dalam Memecahkan Masalah Aljabar Ditinjau dari Kecerdasan Linguistik dan Kecerdasan Logis-Matematis
}

\author{
Mochamad Alfian Mukti Pradana \\ Pendidikan Matematika, Fakultas Matematika dan Ilmu Pengetahuan Alam, Universitas Negeri Surabaya \\ mochamadp@mhs.unesa.ac.id \\ Ismail \\ Pendidikan Matematika, Fakultas Matematika dan Ilmu Pengetahuan Alam, Universitas Negeri Surabaya \\ ismail@unesa.ac.id
}

\begin{abstract}
Abstrak
Setiap Individu siswa memiliki kapasitas dan karakteristik antisipasi yang berbeda sehingga langkah dalam pemecahan masalah yang dilakukan juga berbeda. Perbedaan tersebut disebabkan karena setiap siswa memiliki lebih dari satu jenis kecerdasan yang berbeda. Untuk memecahkan masalah matematika, dibutuhkan pemahaman dan pemikiran logis yang baik. Pemahaman berhubungan dengan kecerdasan linguistik sedangkan pemikiran logis berhubungan dengan kecerdasan logis-matematis. Tujuan penelitian ini adalah untuk mendeskripsikan antisipasi siswa berdasarkan kecerdasan linguistik dan kecerdasan logis-matematis dalam memecahkan masalah aljabar. Penelitian ini merupakan penelitian deskriptif menggunakan pendekatan kualitatif dengan metode tes dan wawancara. Subjek yang digunakan dalam penelitian adalah tiga siswa yaitu satu siswa dengan kecerdasan linguistik tinggi dan kecerdasan logis-matematis tinggi, satu siswa dengan kecerdasan linguistik tinggi dan kecerdasan logis-matematis rendah, dan satu siswa dengan kecerdasan linguistik rendah dan kecerdasan logismatematis tinggi. Kesimpulan yang diperoleh pada penelitian ini adalah antisipasi siswa yang mempunyai kecerdasan linguistik tinggi dan kecerdasan logis-matematis tinggi dalam memecahkan masalah aljabar adalah antisipasi eksploratif, siswa melakukan penyelesaian masalah secara tidak spontan, saat membaca masalah melakukan aktivitas lain, menggabungkan beberapa konsep tentang masalah, melakukan pemecahan masalah sesuai dugaan dan mengevaluasinya kembali. Antisipasi siswa yang mempunyai kecerdasan linguistik tinggi dan kecerdasan logis-matematis rendah dalam memecahkan masalah aljabar adalah antisipasi analitik, siswa melakukan pemecahan masalah secara tidak spontan, saat membaca masalah melakukan aktivitas lain yaitu mengaris bawahi dan melingkari. Siswa membuat dugaan jawaban dan langkah-langkah pemecahan masalah. Siswa mempertimbangkan alternatif pemecahan lain dan mengevaluasi kembali pemecahan masalahnya. Antisipasi siswa yang mempunyai kecerdasan linguistik rendah dan kecerdasan logis-matematis tinggi dalam memecahkan masalah aljabar adalah antisipasi kaku, siswa melakukan aktivitas lain yaitu menggaris bawahi kata yang dibaca. Siswa malakukan pemecahan masalah sesuai dugaan. Siswa tidak mempertimbangkan alternatif pemecahan lain. Siswa mengabaikan informasi baru yang relevan dengan masalah. Siswa tidak mengevaluasi kembali pemecahan masalahnya.
\end{abstract}

Kata Kunci: Pemecahan Masalah Aljabar, Kecerdasan Linguistik, Kecerdasan Logis-Matematis.

\section{It th}

Each individual student has different anticipation capacities and characteristics so the steps in solving the problem are also different. The difference is caused each student has more than one different type of intelligence. To solve mathematical problems, good understanding and logical thinking are needed. Understanding is related to linguistic intelligence, while logical thinking is related to logical-mathematical intelligence. The purpose of this research is to describe students' anticipation based on linguistic intelligence and logical-mathematical intelligence in solving algebraic problems. This research is a descriptive research using a qualitative approach with test and interview methods. The subject used in the research are three students, namely one student with high linguistic intelligence and high logical-mathematical intelligence, one student with high linguistic intelligence and low logicalmathematical intelligence, and one student with low linguistic intelligence and high logical-mathematical intelligence. The Conclusions obtained in this research are anticipation of students who have high linguistic intelligence and high logical-mathematical intelligence in solving algebraic problems is exploratory anticipation, students do problem solving non-spontaneously, when reading problems doing other activities, combining several concepts about problems, doing solving problems as expected and evaluating them again. Anticipation of students who have high linguistic intelligence and low logical-mathematical intelligence in solving algebraic problems is 
analytical anticipation, students do problem solving non-spontaneously, when reading problems doing other activities that are underlining and circling. Students make guesses about answers and problem solving steps. Students consider other alternative solutions and reevaluate problem solving. Anticipation of students who have low linguistic intelligence and high logical-mathematical intelligence in solving algebraic problems is stiff anticipation, students do other activities which are underlining the words that are read. Students perform problem solving as expected. Students do not consider other alternative solutions. Students ignore new information that is relevant to the problem. Students do not reevaluate the problem solving.

Keywords: Algebraic Problem Solving, Linguistic Intelligence, Logical-Mathematical Intelligence.

\section{PENDAHULUAN}

Solso dalam Hudojo (2003) mengungkapkan bahwa pemecahan masalah merupakan aktivitas berpikir yang diarahkan pada penyelesaian masalah tertentu yang melibatkan baik pembentukan respon-respon maupun pemilihan di antara respon-respon yang mungkin. Sedangkan Polya (1973) mendefinisikan pemecahan masalah sebagai usaha mencari jalan keluar dari suatu kesulitan. Berdasarkan beberapa pengertian di atas, pemecahan masalah dalam matematika adalah suatu aktivitas untuk mencari solusi dari soal matematika yang dihadapi dengan melibatkan semua bekal pengetahuan dan bekal pengalaman yang tidak menuntut adanya pola khusus mengenai cara atau strategi penyelesaiannya.

Kemampuan pemecahan masalah matematis siswa penting untuk dikembangkan. Perihal memecahkan masalah matematika, siswa pasti memanfaatkan pengetahuannya dalam berpikir sebelum melakukan tindakan mental (berpikir) melalui proses pemahaman di dalam otaknya yang berarti langkah awal yang harus dimiliki siswa dalam menyelesaikan masalah yaitu memahami apa yang akan dikerjakan dan apa yang akan dihasilkan. Siswa harus meramalkan hasil yang akan diperoleh pada akhir penyelesaian masalah. Dengan demikian, siswa pasti memiliki bayangan ke depan tentang solusi akhir permasalahan sekalipun yang ia bayangkan salah. Makna solusi akhir tertentu di sini adalah bahwa setiap langkah/tahapan tertentu dari suatu masalah yang diselesaikan, siswa memiliki solusi sementara sebelum melanjutkan ke langkah/tahapan berikutnya (Lim, 2007). Suatu tindakan meramalkan yang dilakukan oleh seseorang dalam menghadapi situasi baru atau persoalan tertentu ini disebut antisipasi.

Lim (2006) mendefinisikan lima antisipasi yaitu (1) antisipasi impulsif, (2) antisipasi terinternalisasi, (3) antisipasi kaku, (4) antisipasi eksploratif, dan (5) antisipasi analitik. Setiap individu siswa memiliki kapasitas dan karakteristik antisipasi yang berbeda sehingga produk yang dihasilkan juga berbeda. Perbedaan ini disebabkan karena setiap siswa terlahir dengan jenis inteligensi yang berbeda. Dalam menyelesaikan suatu permasalahan matematika dibutuhkan pemahaman, analisis, perhitungan dan imajinasi yang tinggi sehingga dapat dikatakan bahwa dalam menyelesaikan suatu permasalahan membutuhkan kecerdasan linguistik, logis-matematis dan visual-spasial. Namun dalam penelitian ini, yang akan dibahas hanya fokus pada kecerdasan linguistik dan kecerdasan logismatematis karena peneliti menganggap dua kecerdasan inilah yang ada kaitannya dengan antisipasi siswa dalam menyelesaikan masalah matematika.

Ketika menyelesaikan suatu masalah, siswa harus memahami terlebih dahulu permasalahan yang dihadapi, ini membutuhkan kemampuan bahasa dan komunikasi yang baik. Hal ini berhubungan dengan kecerdasan linguistik. Selain bahasa, dalam menyelesaikan suatu masalah matematika juga dibutuhkan pemikiran logis. Hal ini berhubungan dengan kecerdasan logis-matematis yang dimiliki seseorang. Dengan demikian dapat disimpulkan bahwa pada kegiatan antisipasi dalam menyelesaikan masalah paling tidak dibutuhkan dua kecerdasan yaitu: kecerdasan linguistik dan kecerdasan logis-matematis. Kecerdasan linguistik dibutuhkan siswa untuk mampu memahami permasalahan dan dapat mengungkapkan pikiran atau pendapatnya, sedangkan kecerdasan logismatematis diperlukan untuk memahami dan menganalisis pola, menyelesaikan masalah dengan kemampuan berpikir karena matematika sendiri dikembangkan melalui pemikiran logis. Dengan demikian untuk mengetahui dan mendeskripsikan bagaimana kecerdasan linguistik dan logis-matematis berkaitan dengan antisipasi siswa dalam pemecahan masalah matematika maka dilakukanlan penelitian ini.

\section{METODE}

Penelitian ini merupakan penelitian deskriptif dengan pendekatan kualitatif. Untuk memperoleh data yang diperlukan, dilakukan pemberian angket kecerdasan majemuk, tes pemecahan masalah aljabar, dan wawancara. Penelitian ini dilaksanakan di SMA Al Azhar Gresik pada semester genap tahun pelajaran 2018/2019. Subjek yang digunakan adalah 3 (tiga) siswa kelas X MIA Intensif B terpilih dari hasil angket kecerdasan majemuk. Subjek tersebut diambil satu dari masing-masing siswa; (a) yang mempunyai kecerdasan linguistik tinggi dan kecerdasan logis-matematis tinggi, (b) yang mempunyai kecerdasan linguistik tinggi dan kecerdasan logis-matematis rendah dan (c) yang mempunyai kecerdasan linguistik rendah dan kecerdasan logis-matematis tinggi. 
Pemilihan subjek dilakukan dengan memberikan angket terlebih dahulu. Angket ini diadopsi dari buku Pembelajaran Berbasis Multiple Intelleigences karya Yaumi (2012) oleh peneliti dan dikonsultasikan kepada dosen pembimbing. Angket ini dilakukan dengan memberikan 80 pernyataan berskor yang harus diisi oleh siswa. Selanjutnya diberikan tes pemecahan masalah secara individu. Tes ini diujikan kepada tiga subjek penelitian yang telah terpilih. Berikutnya adalah Metode Think Aloud dan wawancara terhadap subjek terpilih. Pengumpulan data menggunakan metode think aloud, yaitu; siswa diminta untuk menyampaikan secara lisan apa yang dipikirkan selama proses penyelesaian masalah. Metode wawancara yang digunakan adalah wawancara berbasis tugas, wawancara tersebut dilakukan setelah subjek menyelesaiakan masalah aljabar. Kegiatan ini dilakukan untuk memperjelas data yang diperoleh dari metode think aloud. Dalam penelitian ini, peneliti melakukan wawancara dengan langkah-langkah sebagai berikut:

a. Siswa diwawancarai berdasarkan jawaban yang sudah dikerjakan pada saat tes tertulis.

b. Pada saat mewawancarai agar data yang diperoleh akurat, maka peneliti menggunakan rekam audio untuk merekam proses wawancara antara peneliti dengan subjek.

Data dalam penelitian ini adalah hasil tes tulis pemecahan masalah dengan menggunakan metode think aloud dan penjelasan siswa dalam wawancara. Selanjutnya teknik analisis data yang digunakan dalam penelitian ini adalah teknik analisis data kualitatif. Teknik analisis data yang digunakan adalah reduksi data, penyajian data, dan penarikan kesimpulan.

\section{HASIL DAN PEMBAHASAN}

Hasil Penelitian

Pengambilan data dilaksanakan di di SMA Al Azhar Gresik pada semester genap tahun pelajaran 2018/2019. Berikut ini adalah tabel kegiatan pengambilan data.

Tabel 1. Kegiatan Pengambilan Data

\begin{tabular}{|c|l|c|}
\hline No & \multicolumn{1}{|c|}{ Kegiatan } & Tanggal \\
\hline 1 & $\begin{array}{l}\text { Permohonan izin penelitian Kepala } \\
\text { Sekolah }\end{array}$ & $\begin{array}{c}\text { 12 Juni } \\
2019\end{array}$ \\
\hline 2 & $\begin{array}{l}\text { Pemberian angket kecerdasan } \\
\text { majemuk }\end{array}$ & $\begin{array}{c}\text { 13 Juni } \\
2019\end{array}$ \\
\hline 3 & $\begin{array}{l}\text { Tes pemecahan masalah dengan } \\
\text { menggunakan metode think aloud } \\
\text { dan wawancara untuk subjek yang } \\
\text { terpilih }\end{array}$ & 3 Juli 2019 \\
\hline
\end{tabular}

Penelitian melibatkan 32 siswa kelas X MIA Intensif B yang merupakan rekomendasi dari guru mitra. Penelitian diawali dengan pemberian angket kecerdasan majemuk terhadap seluruh siswa kelas X MIA Intensif B. Angket kecerdasan majemuk terdiri dari 80 pernyataan yang memiliki skor 1, 2, 3, 4, dan 5. Setelah pengisian angket, dilakukan penyekoran terhadap pernyataan siswa. Dari skor yang diperoleh siswa dikelompokkan dalam kategori kecerdasan majemuk tinggi, sedang, dan rendah. Berikut kriteria tingkat kecerdasan majemuk.

Tabel 2. Kriteria Tingkat Kecerdasan Majemuk Siswa

\begin{tabular}{|c|c|}
\hline Tingkat Kecerdasan & Kriteria \\
\hline Tinggi & $35<$ Skor $\leq 50$ \\
\hline Sedang & $15<$ Skor $\leq 35$ \\
\hline Rendah & Skor $\leq 15$ \\
\hline
\end{tabular}

Setelah diperoleh hasil, kemudian dilakukan konsultasi terhadap guru mitra. Berikut ketiga siswa yang dipilih menjadi subjek penelitian:

Tabel 3. Subjek Terpilih

\begin{tabular}{|c|c|c|l|}
\hline No & Nama & Kode & \multicolumn{1}{|c|}{ Keterangan } \\
\hline 1 & MLAB & S1 & $\begin{array}{l}\text { Kecerdasan linguistik tinggi dan } \\
\text { kecerdasan logis-matematis tinggi }\end{array}$ \\
\hline 2 & MSF & S2 & $\begin{array}{l}\text { Kecerdasan linguistik tinggi dan } \\
\text { kecerdasan logis-matematis } \\
\text { rendah }\end{array}$ \\
\hline 3 & MSM & S3 & $\begin{array}{l}\text { Kecerdasan linguistik rendah dan } \\
\text { kecerdasan logis-matematis tinggi }\end{array}$ \\
\hline
\end{tabular}

Analisis Data Antisipasi Siswa dalam Memecahkan Masalah Aljabar pada Subjek dengan Kecerdasan Linguistik Tinggi dan Kecerdasan Logis-matematis Tinggi

Masalah nomor 1

Pada Gambar 1 berikut ini merupakan gambar pekerjaan siswa dengan tingkat kemampuan matematika tinggi untuk permasalahan nomor 1 .

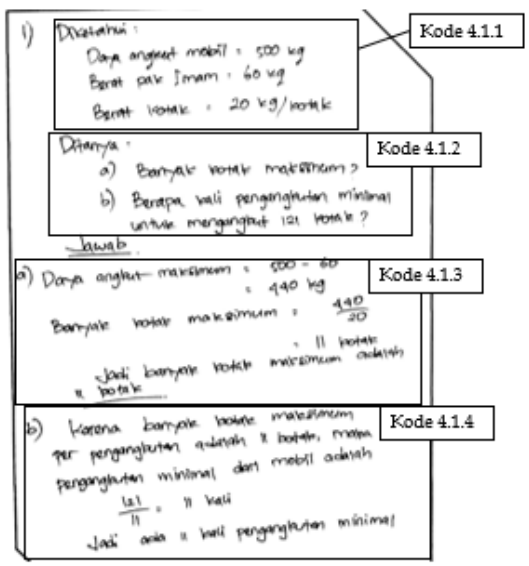

Gambar 1. Lembar Jawaban Masalah Nomor 1 Subjek S1

Pada gambar 1 subjek S1 menuliskan apa yang diketahui pada kode 4.1.1. Kode 4.1.2 dituliskan apa yang ditanyakan. Selanjutnya subjek S1 menjawab kedua poin tersebut sampai diperoleh kesimpulan banyak kotak maksimum adalah 11 kotak dan ada 11 kali minimal pengangkutan seperti pada kode 4.1.3 dan kode 4.1.4. 
Berikut adalah cuplikan transkrip wwancara dengan subjek S1.

$\begin{array}{|ll|}\text { W1.1.1 } & \text { : Kamu tadi membaca soal tersebut berapa kali } \\ \text { S1.1.1 } & \text { : Tiga kali untuk memahami soal dengan lebih. } \\ \text { W1.1.2 } & \text { : Saat membaca tadi, apa yang kamu lakukan? } \\ \text { S1.1.2 } & \text { : Membaca dan menunjuk kata-kata kunci pada } \\ \text { Woal agar lebih fokus. } & \text { : Oke, terus bagaimana caramu mengetahui apa } \\ \text { S1.1.3 } & \begin{array}{l}\text { yang diketahui dan apa yang ditanyakan? } \\ \text { :Ya itu tadi pak, membaca dan mengikuti alur } \\ \text { cerita soal tadi. Kemudian membaca ulang untuk } \\ \text { memastikan. }\end{array}\end{array}$

Gambar 2. Cuplikan Transkrip Wawancara dengan Subjek S1

Berdasarkan hasil wawancara kode W1.1.1 sampai S1.1.3 diketahui bahwa subjek S1 memenuhi indikator 4a dan 5a. Dari pernyataan think aloud tersebut dan transkrip wawancara kode W1.1.2 dan S1.12 diketahui bahwa subjek S1 saat membaca masalah melakukan aktivitas lain yaitu menunjuk kata-kata kunci yang dibaca. Sehingga berdasarkan uraian tersebut maka subjek S1 memenuhi indikator $2 \mathrm{a}, 4 \mathrm{~b}$ dan 5 b.Untuk mengetahui indikator antisipasi yang lain dari subjek S1 dapat dilihat dari kutipan transkrip wawancara berkut ini:

\begin{tabular}{|c|c|}
\hline$W 1.1 .5$ & $\begin{array}{l}\text { : Masalah nomor } 1 \text { tadi itu tentang apa atau } \\
\text { materi apa menurutmu? }\end{array}$ \\
\hline S1.1.5 & : Oh, pertidaksamaan pak \\
\hline W1.1.6 & : Mengapa? \\
\hline S1.1.6 & $\begin{array}{l}\text { : Itu pak karena ada kata tidak lebih dari pada } \\
\text { masalah nomor } 1 \text { tadi. }\end{array}$ \\
\hline W1.1.7 & $\begin{array}{l}\text { : Oke, selanjutnya bagaimana perencanaanmu } \\
\text { dalam menyelesaikan masalah itu tadi? }\end{array}$ \\
\hline S1.1.7 & $\begin{array}{l}\text { : Begini pak, saya tadi menulis yang diketahui } \\
\text { dan yang ditanyakan. Kemudian menyelesaikan } \\
\text { operasi yang berkaitan sesuai alur soal itu tadi } \\
\text { pak. }\end{array}$ \\
\hline W1.1.8 & $\begin{array}{l}\text { : Begitu ya, coba ceritakan caramu tadi } \\
\text { menyelesaikan masalah nomor } 1 !\end{array}$ \\
\hline S1.1.8 & $\begin{array}{l}\text { : Pertama saya mencari daya angkut maksimal } \\
\text { mobil box itu tadi pak. Lalu mencari dan } \\
\text { menghitung banyak kotak maksimumnya. Dan } \\
\text { saya menggunakan hasil dari pertanyaan } \\
\text { sebelumnya untuk menghitung banyak } \\
\text { pengangkutannya pak. }\end{array}$ \\
\hline
\end{tabular}

Gambar 3. Cuplikan 2 Transkrip Wawancara dengan Subjek S1

Berdasarkan kutipan transkrip wawancara kode W1.1.5 sampai S1.1.8, gambar kode 4.1.1, kode 4.13 dan 4.1.4 serta pernyataan $\mathrm{S}_{1.1 .1}$ dapat diketahui bahwa subjek S1 menggabungkan beberapa konsep tentang masalah dan melakukan pemecahan masalah sesuai dugaan. Hal tersebut menunjukkan bahwa subjek $\mathrm{S} 1$ memnuhi indikator 1d, 2b, 3c, 4c, 5c, dan 5d. Adapun dari transkrip wawancara kode S1.1.13 diketahui bahwa subjek S1 mengevaluasi kembali pemecahan masalahnya. Hal ini menunjukkan bahwa subjek S1 memenuhi indikator 4e dan 5e.
Masalah nomor 2

Gambar berikut ini merupakan jawaban dari subjek untuk permasalahan nomor 2 .

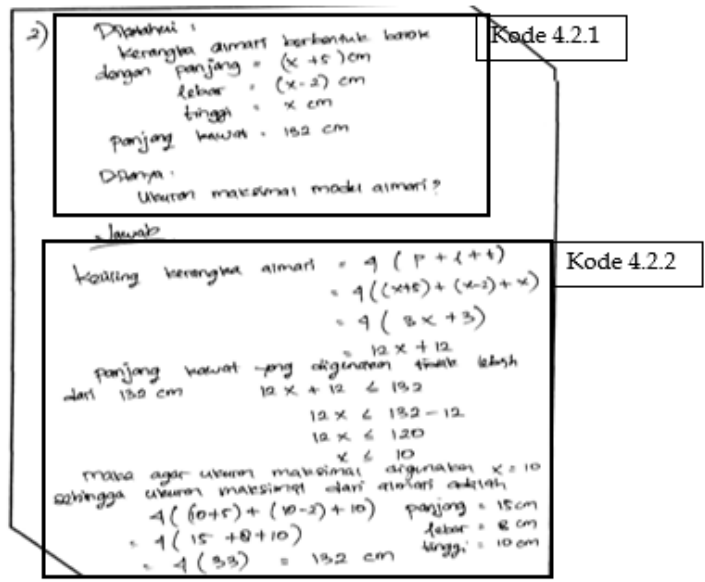

Gambar 5. Lembar Jawaban Masalah Nomor 2 Subjek S1

Pada gambar 5 subjek S1 menuliskan apa yang diketahui dan apa yang ditanyakan pada gambar kode 4.2.1. Selanjutnya pada gambar kode 4.2.2 subjek S1 menjawab dengan menghitung keliling rangka almari terlebih dahulu. Setelah didapat model matematikanya dia mencari ukuran maksimal dari panjang, lebar, dan tinggi almari tersebut. Selanjutnya disajikan pernyataan yang diungkapkan oleh subjek S1 selama penyelesaian masalah nomor 2 .

Berikut adalah kutipan transkrip wawancara dengan subjek S1:

\begin{tabular}{|c|c|}
\hline$W 1.2 .1$ & $\begin{array}{l}\text { : Berapa kali kamu membaca soal nomor } 2 \\
\text { sebelum mengerjakan? Mengapa? }\end{array}$ \\
\hline$S 1.2 .1$ & $\begin{array}{l}\text { : Kalau nomor } 2 \text { ini dua kali pak karena untuk } \\
\text { memahaminya. }\end{array}$ \\
\hline W1.2.2 & : Saat membaca tadi, apa yang kamu lakukan? \\
\hline$S 1.2 .2$ & $\begin{array}{l}\text { : Membaca dan membaca lagi sambil menunjuk } \\
\text { kata-kata kunci pada soal agar lebih fokus pada } \\
\text { kata kunci tersebut. }\end{array}$ \\
\hline
\end{tabular}

Gambar 4. Cuplikan 3 Transkrip Wawancara dengan Subjek S1

Berdasarkan pernyataan $\mathrm{S}_{1.2 .1}$ dan kutipan transkrip diatas dapat diketahui bahwa subjek S1 tidak spontan menyelesaikan masalah dan melakukan aktivitas lain saat membaca yaitu menunjuk kata yang dibaca. Hal ini menunjukkan bahwa subjek S1 memenuhi indikator 2a, 4a, 5a, 4b, dan 5b. Dari gambar kode 4.2.2 subjek S1 menuliskan penyelesaian beserta langkah pemecahan masalahnya untuk menemukan jawaban. Hal ini menunjukkan bahwa subjek S1 melakukan pemecahan masalah sesuai dugaan dan menggabungkan beberapa konsep tentang masalah. Adapun kutipan transkrip wawancara yang mendukung hal tersebut adalah sebagai berikut: 


\begin{tabular}{|c|c|}
\hline W1.2.4 & $\begin{array}{l}\text { : Setelah itu, menurutmu konsep apa yang } \\
\text { ada pada masalah nomor } 2 \text { tersebut? }\end{array}$ \\
\hline S1.2.4 & : Bangun ruang. \\
\hline W1.2.5 & : Apakah hanya itu? Mengapa? \\
\hline$S 1.2 .5$ & $\begin{array}{l}\text { : Pertidaksamaan juga seperti nomor } 1 \\
\text { karena ada kalimat tidak lebih dari dan } \\
\text { ukuran maksimal pada soal tersebut. (sambil } \\
\text { menunjuk yang dimaksud) }\end{array}$ \\
\hline W1.2.6 & $\begin{array}{l}\text { : Bagaimana rencanamu tadi untuk } \\
\text { menyelesaikan masalah nomor } 2 ? \text { Jelaskan! }\end{array}$ \\
\hline S1.2.6 & $\begin{array}{l}\text { : Menulis apa yang diketahui dan } \\
\text { ditanyakan. Mengingat rumus keliling balok } \\
\text { dan menyelesaikan operasi sesuai alur soal. }\end{array}$ \\
\hline $\begin{array}{l}\text { W1.2.7 } \\
\text { penyeless }\end{array}$ & $\begin{array}{l}\text { : Selanjutnya coba ceritakan } \\
\text { ainnya! }\end{array}$ \\
\hline S1.2.7 & $\begin{array}{l}\text { : Saya menulis rumus keliling balok dan } \\
\text { memasukkan semua angka yang diketahui. }\end{array}$ \\
\hline
\end{tabular}

Gambar 6. Culikan 4 Transkrip Wawancara dengan Subjek S1

Sehingga dapat diperoleh bahwa subjek S1 memenuhi indikator 1d, 2b, 3c, 4c, 5c, dan 5d. Selanjutnya berdasarkan gambar kode 4.2.2, pernyataan think aloud $\mathrm{S}_{1.2 .1}$ dan transkrip wawancara kode S1.2.12 diketahui bahwa subjek S1 mengevaluasi kembali pemecahan masalahnya. Hal ini menunjukkan subjek S1 memenuhi indikator $4 \mathrm{e}$ dan $5 \mathrm{e}$.

Kesimpulan Analisis Data Antisipasi Subjek S1 dalam Memecahkan Masalah Aljabar

Berdasarkan analisis data di atas maka dibuat tabel tentang hasil analisis data tes pemecahan masalah aljabar dengan metode think aloud dan wawancara subjek S1. Hal tersebut dilakukan untuk menyajikan data lebih mudah dipahami. Sehingga dapat disimpulkan analisis data antisipasi subjek S1 tersebut.

Tabel 4. Hasil Analisis Data TPM dan Wawancara Subjek S1

\begin{tabular}{|c|c|c|c|}
\hline No. & Indikator & $\begin{array}{c}\text { Soal } \\
1\end{array}$ & Soal 2 \\
\hline 1. & $\begin{array}{l}\text { Penyelesaian dilakukan secara } \\
\text { spontan }\end{array}$ & $x$ & $x$ \\
\hline 2. & $\begin{array}{l}\text { Saat membaca masalah } \\
\text { melakukan aktivitas lain }\end{array}$ & $\checkmark$ & $\checkmark$ \\
\hline 3. & $\begin{array}{l}\text { Beberapa konsep tentang konsep } \\
\text { digabungkan }\end{array}$ & $\checkmark$ & $\checkmark$ \\
\hline 4. & $\begin{array}{l}\text { Pemecahan masalah sesuai } \\
\text { dugaan }\end{array}$ & $\checkmark$ & $\checkmark$ \\
\hline 5. & $\begin{array}{l}\text { Pemecahan masalah dievaluasi } \\
\text { kembali }\end{array}$ & $\checkmark$ & $\checkmark$ \\
\hline
\end{tabular}

Dari Tabel 4 di atas dapat dilihat bahwa indikator antisipasi subjek S1 pada soal nomor 1 dan nomor 2 sama. Indikatorindikator tersebut menunjukkan bahwa antisipasi dominan subjek S1 dalam memecahkan masalah aljabar adalah antisipasi eksploratif.

Analisis Data Antisipasi Siswa dalam Memecahkan Masalah Aljabar pada Subjek dengan Kecerdasan
Linguistik Tinggi dan Kecerdasan Logis-matematis Rendah

Masalah nomor 1

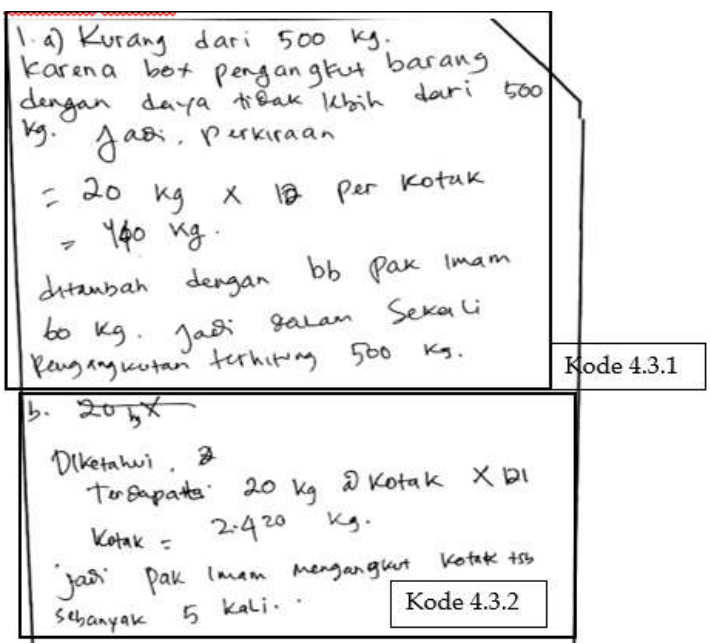

Gambar 7. Lembar Jawaban Masalah Nomor 1 Subjek S2

Pada Gambar 7 subjek S2 menuliskan beberapa kalimat informasi yang diperoleh setelah membaca beberapa kali dan langsung menghitungnya. Pada gambar kode 4.3.1 ada dua bilangan yang diubah nilainya. Subjek memperkirakan perhitungan dan hasilnya sampai diperoleh jawaban kesimpulan. Pada gambar kode 4.3.2 subjek S2 menulis 20 kali kemudian dicoret dan menuliskan apa yang dia ketahui dari masalah tersebut. Melakukan perhitungan sederhana dan memperkirakan hasilnya sampai ditemukan hasil sebanyak 5 kali.

Hasil wawancara dengan subjek S2 ditranskrip dan diberi kode. Untuk mengetahui indikator antisipasi subjek S2 dalam memecahkan masalah aljabar berikut kutipan transkrip wawancara dengan subjek S2:

W2.1.1 : Kamu tadi membaca soal tersebut berapa kali sebelum mengerjakan? Mengapa?

S2.1.1 : Lima kali karena membutuhkan pemahaman dari setiap kata agar bisa diserap oleh rangsangan otak.

W2.1.2 : Pada saat membaca tadi, apa saja yang kamu lakukan?

S2.1.2 : Saya tadi menggaris bawahi kalimat yang penting dan melingkari angka-angkanya sambil menghitung dan berpikir.

Gambar 8. Cuplikan 1 Transkrip Wawancara Subjek S2

Berdasarkan kutipan wawancara kode W2.1.1 sampai S2.1.2 dapat diketahui bahwa subjek S2 melakukan penyelesaian secara tidak spontan ditandai dengan membaca masalah lebih dari satu kali. Hal ini menunjukkan bahwa subjek S2 memenuhi indikator 4a dan 5a. Dari pernyataan dan kutipan transkrip tersebut juga dapat diperoleh bahwa subjek S2 melakukan aktivitas lain saat 
membaca masalah. Hal tersebut menunjukkan bahwa subjek S2 memenuhi indikator 2a, 4b, dan 5 b.

Subjek S2 melakukan pemecahan masalah sesuai dugaan. Hal ini dapat dilihat dari gambar kode 4.3.1 dan gambar kode 4.3.2, pernyataan think aloud $\mathrm{S}_{2.1 .1}$ serta kutipan transkrip wawancara dengan subjek S2 berikut:

$\begin{array}{cl}\text { W2.1.7 } & \begin{array}{l}\text { : Oke, selanjutnya bagaimana perencanaanmu } \\ \text { dalam menyelesaikan masalah itu tadi? }\end{array} \\ \text { S2.1.7 } & \begin{array}{l}\text { :Dengan menggunakan rumus, saya menghtung } \\ \text { dan juga menalarnya berdasarkan angka dan } \\ \text { W2.1.8 }\end{array} \\ \text { pertanyaan pada masalah itu tadi pak. } \\ \text { : Begitu ya, coba jelaskan caramu tadi } \\ \text { menyelesaikan masalah nomor 1! } \\ \text { :Awalnya saya berimajinasi menjadi pak Imam } \\ \text { dan membayangkan mobil, kotak, dan mobil } \\ \text { berjalan mengangkutnya pak. Lalu saya } \\ \text { menghitung counting gitu pak dan menalar agar } \\ \text { sesuai dengan jawaban yang diinginkan, ecetra. }\end{array}$

Gambar 9. Cuplikan 2 Transkrip Wawancara subjek S2

Sehingga subjek S2 memenuhi indikator 1d, 2b, 3c, 4c, dan 5c.Berikut adalah kutipan transkrip wawancara dengan subjek S2 untuk mengetahui indikator yang lain.

W2.1.10 : Apakah ada cara lain untuk menyelesaikan masalah nomor 1 tersebut selain yang sudah kamu lakukan?

S2.1.10 : Mungkin ada cara yang praktis dan mudah namun tidak saya ketahui pak hehe.

W2.1.11 : Apa yang membuatmu menyadari ada alternatif jawaban lain?

S2.1.11 : Karena matematika selalu mempunyai rumus dalam satuan berat.

W2.1.12 : Selanjutnya apakah kamu yakin jawabanmu sudah benar? Mengapa?

S2.1.12 : Yakin benar karena menurut nalar dan perhitungan berdasarkan rumus yang saya pakai dapat menemukan jawaban yang sesuai.

W2.1.13 :Apakah kamu sudah mengecek ulang hasil jawabanmu tadi? Bagaimana?

S2.1.13 : Sudah saya cek dua kali.

Gambar 10. Cuplikan 3 Transkrip Wawancara S2

Dari transkrip wawancara kode W2.1.10 sampai S2.1.13, gambar kode 4.3.1 dan kode 4.3.2 serta pernyataan think aloud $\mathrm{S}_{2.1 .1}$ dapat diketahui bahwa subjek S2 mempertimbangkan alternatif pemecahan lain dan mengevaluasi kembali pemecahan masalah tersebut. Hal ini menunjukkan bahwa subjek S2 memenuhi indikator 3d, $4 \mathrm{~d}, 4 \mathrm{e}$, dan $5 \mathrm{e}$.

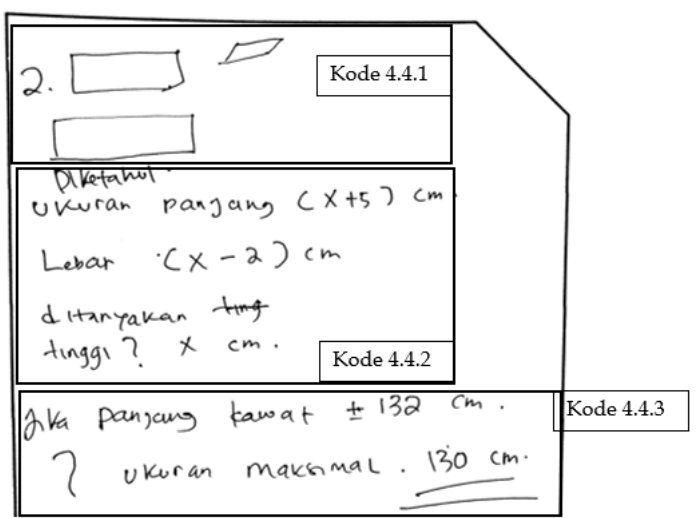

Gambar 11. Lembar Jawaban Masalah Nomor 2 Subjek S2

Pada Gambar 11 subjek S2 menggambar beberapa bangun datar pada kode 4.4.1 dan apa yang diketahuinya pada gambar kode 4.4.2. Selanjutnya dia menjawab dengan memperkirakan kurang lebihnya sehingga diperoleh hasil $130 \mathrm{~cm}$ seperti pada gambar kode 4.4.3. Berikut adalah transkrip wawancara dengan subjek S2 untuk melihat indikator antisipasi siswa yang dialami:

$\begin{array}{cl}\text { W2.2.1 } & \text { : Berapa kali kamu membaca soal nomor } 2 \\ \text { S2.2.1 } & \begin{array}{l}\text { : Lebih dari } 5 \text { kali pak karena soalnya lebih susah } \\ \text { dan ada variabel-variabelnya juga. }\end{array} \\ \text { W2.2.2 } & \begin{array}{l}\text { : Pada saat membaca tadi, apa saja yang kamu } \\ \text { lakukan? }\end{array} \\ & \text { : Sama dengan yang nomor } 1 \text { pak, membaca } \\ & \text { sambil menggaris bawahi kalimat pentin dan } \\ \text { melingkari kata serta angka yang menurut saya } \\ \text { krusial. Saya juga menggambar bentuk model } \\ \text { dari soal tersebut. }\end{array}$

Gambar 12. Cuplikan 3 Transkrip Wawancara S2

Berdasarkan kutipan transkrip di atas dapat diketahui bahwa subjek S2 melakukan penyelesaian secara tidak spontan dan melakukan aktivitas lain saat membaca masalah. Hal ini menunjukkan bahwa subjek S2 memenuhi indikator 4a, 4b, 5a, dan 5b.

Selanjutnya dari gambar kode 4.4.2, kode 4.4.3 serta transkrip wawancara kode W2.2.9 sampai S2.2.13 dapat diketahui bahwa subjek S2 melakukan pemecahan masalah sesuai dugaan. Alternatif pemecahan masalah lain dipertimbangkan dan mengevaluasi kembali pemecahan masalahnya. Hal ini menunjukkan bahwa subjek S3 memenuhi indikator 1d, 2b, 3c, 4c, 4d, 4e, 5d, dan 5e.

Kesimpulan Analisis Data Antisipasi Subjek S2 dalam Memecahkan Masalah Aljabar

Berdasarkan analisis data di atas maka dibuat tabel tentang hasil analisis data tes pemecahan masalah aljabar dengan metode think aloud dan wawancara subjek S2. Hal tersebut dilakukan untuk menyajikan data lebih mudah dipahami. 
Sehingga dapat disimpulkan analisis data antisipasi subjek S2 tersebut.

Tabel 5. Hasil Analisis Data TPM dan Wawancara Subjek S2

\begin{tabular}{|c|l|c|c|}
\hline No. & \multicolumn{1}{|c|}{ Indikator } & Soal 1 & Soal 2 \\
\hline 1. & $\begin{array}{l}\text { Penyelesaian dilakukan secara } \\
\text { spontan membaca masalah }\end{array}$ & $\checkmark$ & × \\
\hline 2. & $\begin{array}{l}\text { Saat melakukan aktivitas lain } \\
\text { melaku konsep tentang }\end{array}$ & $\times$ & $\times$ \\
\hline 3. & $\begin{array}{l}\text { Beberapa } \\
\text { konsep digabungkan }\end{array}$ & $\checkmark$ & $\checkmark$ \\
\hline 4. & $\begin{array}{l}\text { Pemecahan masalah sesuai } \\
\text { dugaan }\end{array}$ & $\checkmark$ & $\checkmark$ \\
\hline 5. & $\begin{array}{l}\text { Pemecahan masalah dievaluasi } \\
\text { kembali }\end{array}$ & $\checkmark$ \\
\hline 6. & $\begin{array}{l}\text { Alternatif pemecahan masalah } \\
\text { lain dipertimbangkan }\end{array}$ & $\checkmark$ & $\times$ \\
\hline
\end{tabular}

Dari tabel 5 di atas dapat dilihat bahwa indikator antisipasi subjek S2 pada soal nomor 1 dan nomor 2 cenderung sama. Subjek S2 melakukan penyelesaian secara tidak spontan dan menggaris bawahi serta melingkari beberapa kata untuk memahami masalah saat membaca. Subjek S2 membuat langkah pemecahan masalah dan membayangkan sebab-akibat dari alternatif penyelesaian. Subjek S2 juga mengevaluasi kembali pemecahan masalahnya. Berdasarkan beberapa indikator tersebut dapat disimpulkan bahwa dalam memecahkan masalah aljabar antisipasi yang dominan dari subjek S2 adalah antisipasi analitik.

Analisis Data Antisipasi Siswa dalam Memecahkan Masalah Aljabar pada Subjek dengan Kecerdasan Linguistik Rendah dan Kecerdasan Logis-matematis Tinggi

Masalah nomor 1

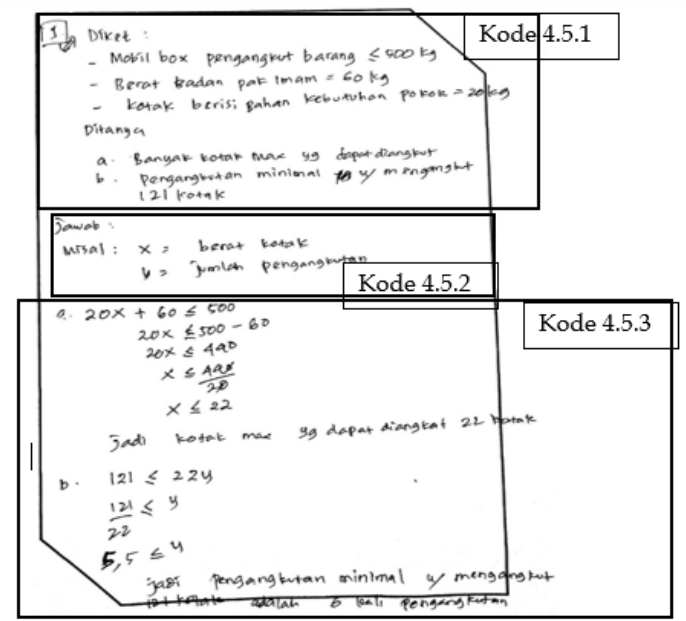

Gambar 13. Lembar Jawaban Masalah Nomor 1 Subjek S3
Pada Gambar 12 subjek S3 menuliskan informasi apa yang diketahui dan tujuan apa yang ditanyakan pada gambar kode 4.5.1. Subjek S3 mengerjakan dengan membuat permisalan terlebih dahulu seperti pada gambar kode 4.5.2. Setelah itu melakukan perhitungan sampai diperoleh hasil pada poin (a) 22 kotak dan pada poin (b) 5,5 yang kemudian dibulatkan menjadi 6 pengangkutan pada gambar kode 4.5.3. Selanjutnya disajikan pernyataan yang diungkapkan oleh subjek S3 selama penyelesaian masalah nomor 1. Berikut kutipan transkrip tersebut untuk melihat indikator antisipasi siswa yang dilakukan:

W3.1.2 : Pada saat membaca tadi, apa saja yang kamu
S3.1.2 $\quad$ : Mengakaris bawahi kalimat tadi itu (sambil
menunjuk yang dimaksud) lalu menulis apa yang
diketahui dari soal kemudian memisalkan dan
memodelkannya.

Gambar 14. Cuplikan 1 Transkrip Wawancara dengan subjek S3

Berdasarkan kutipan subjek S3 melakukan aktivitas lain saat membaca yaitu menggaris bawahi kata dan menulis langsung informasi yang ada. Hal ini menunjukkan bahwa subjek S3 memenuhi indikator 1a, 2a, 4b, dan 5b. Untuk mengetahui indikator lain yang dilakukan subjek S3 berikut kutipan transkrip wawancaranya:

W3.1.7 : Oke, selanjutnya bagaimana perencanaanmu dalam menyelesaikan masalah itu tadi?

S3.1.7 : Dari yang diketahui kemudian dimisalkan dan dikerjakan.

W3.1.8 : Coba jelaskan caramu tadi menyelesaikan masalah nomor 1 !

S3.1.8 : Ya mengerjakan sesuai rencana tadi pak. Pertama saya memisalkan berat kotak dan jumlah pengangkutan selanjutnya memasukkan sesuai model matematikanya. Menghitung samapai ketemu jawaban yang sesuai dari pertanyaan tersebut.

W3.1.9 : Pada waktu mengerjakan tadi kamu merasa ada kesalahan atau ragu di tahap tertentu atau tidak?

S3.1.9 : Hanya pada poin (b) sempat ragu kemudian saya membaca ulang lagi soal secara keseluruhan dan paham.

W3.1.10 : Apakah ada cara lain untuk menyelesaikan masalah nomor 1 tersebut selain yang sudah kamu lakukan?

S3.1.10 : Yakin ada tapi saya tidak mencarinya hehe.

W3.1.11 : Apa yang membuatmu menyadari ada alternatif jawaban lain?

S3.1.11 : Karena ada kalimat tidak lebih dari itu pak.

W3.1.12 : Selanjutnya apakah kamu yakin jawabanmu sudah benar? Mengapa?

S3.1.12 : Yakin karena sudah menemukan jawaban.

W3.1.13 : Apakah kamu sudah mengecek ulang hasil jawabanmu tadi? Bagaimana?

S3.1.13 : Tidak.

Gambar 15. Cuplikan 2 Transkrip Wawancara dengan Subjek S2 
Dari kutipan transkrip wawancara kode W3.1.7 sampai S3.1.13, gambar kode 4.5.1, 4.5.2 dan 4.5.3 dapat diketahui bahwa subjek S3 melakukan pemecahan masalah sesuai dugaan. Tidak mempertimbangkan alternatif pemecahan lain pada masalah sehingga terpenuhi indikator $1 \mathrm{~d}, 2 \mathrm{~b}, 2 \mathrm{c}$, dan 3c. Mengabaikan informasi baru yang relevan dengan masalah maka dipenuhi indikator 2d. subjek S3 juga tidak mengevaluasi pemecahan masalahnya dan memenuhi indikator $2 \mathrm{e}$ dan $3 \mathrm{e}$.

\section{Masalah nomor 2}

Pada Gambar 16 subjek S3 menuliskan apa yang diketahui dalam bentuk matematikanya pada gambar kode 4.6.1. Kemudian menulis tujuan atau apa yang ditanyakan pada masalah nomor 2 tersebut. Selanjutnya dia menjawab dengan diawali menggambar sebuah balok dengan keterangan yang sudah diketahui pada gambar kode 4.6.2. Kemudian menghitung dengan cara mensubtitusi apa yang diketahui pada model matematika dari tujuan soal tersebut.

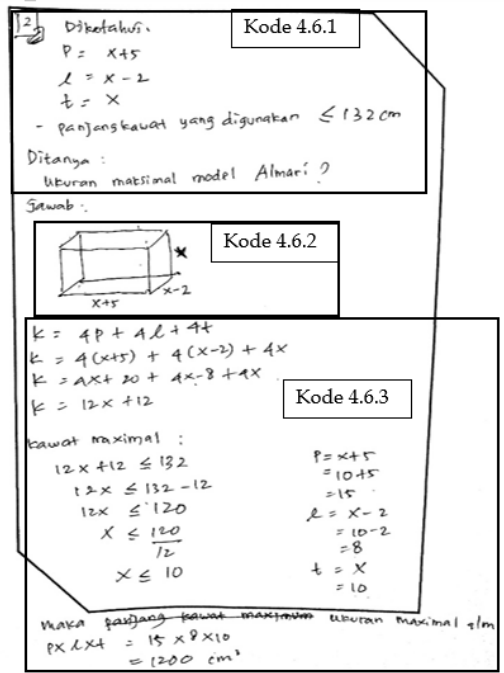

Gambar 16. Lembar Jawaban Masalah Nomor 2 Subjek S3

Selanjutnya disajikan pernyataan yang diungkapkan oleh subjek S3 selama penyelesaian masalah nomor 2 . Berikut adalah kutipan transkrip wawancara dengan subjek S3 untuk menggali indikator antisipasinya:

\begin{tabular}{|ll|}
\hline W3.2.6 & : Bagaimana rencanamu tadi untuk \\
S3.2.6 & $\begin{array}{l}\text { menyelesaikan masalah nomor 2? Jelaskan! } \\
\text { rumus kemudian baru mengerjakan. }\end{array}$ \\
W3.2.7 & : Selanjutnya coba ceritakan penyelesainnya! \\
S3.2.7 & : Saya menggambar terlebih dahulu untuk \\
& menemukan rumus keliling kerangka tadi dan \\
& selanjutnya mengerjakan sesuai rencana.
\end{tabular}

Gambar 17. Cuplikan 3 Transkrip Wawancara dengan Subjek S2
Berdasarkan transkrip wawancara kode W3.2.6 sampai S3.2.7 di atas dapat diketahui bahwa subjek S3 melakukan pemecahan sesuai dugaan. Maka subjek S3 memenuhi indikator $1 \mathrm{~d}, 2 \mathrm{~b}, 3 \mathrm{c}, 4 \mathrm{c}$, dan $5 \mathrm{~d}$. Berdasarkan transkrip wawancara kode W3.2.9 sampai S3.2.12 dan gambar 17 diperoleh bahwa subjek S3 tidak mempertimbangkan alternatif pemecahan lain. Hal ini menunjukkan subjek S3 memenuhi indikator 2c dan 3d. Subjek S3 juga diketahui tidak mengevaluasi kembali pemecahan masalahnya. Hal tersebut menunjukkan bahwa subjek S3 memenuhi indikator 2e dan 3e.

Kesimpulan Analisis Data Antisipasi Subjek S3 dalam Memecahkan Masalah Aljabar

Berdasarkan analisis data di atas maka dibuat tabel tentang hasil analisis data tes pemecahan masalah aljabar dengan metode think aloud dan wawancara subjek S3. Hal tersebut dilakukan untuk menyajikan data lebih mudah dipahami. Sehingga dapat disimpulkan analisis data antisipasi subjek S3 tersebut.

Tabel 6. Hasil Analisis Data TPM dan Wawancara Subjek S3

\begin{tabular}{|c|l|c|c|}
\hline No. & \multicolumn{1}{|c|}{ Indikator } & Soal 1 & Soal 2 \\
\hline 1. & $\begin{array}{l}\text { Penyelesaian dilakukan } \\
\text { secara spontan }\end{array}$ & $\checkmark$ & $\checkmark$ \\
\hline 2. & $\begin{array}{l}\text { Saat membaca masalah } \\
\text { melakukan aktivitas lain }\end{array}$ & $\checkmark$ & $\mathbf{x}$ \\
\hline 3. & $\begin{array}{l}\text { Beberapa konsep tentang } \\
\text { konsep digabungkan }\end{array}$ & $\mathbf{x}$ \\
\hline 4. & $\begin{array}{l}\text { Pemecahan masalah sesuai } \\
\text { dugaan }\end{array}$ & $\checkmark$ & $\checkmark$ \\
\hline 5. & $\begin{array}{l}\text { Pemecahan masalah } \\
\text { dievaluasi kembali }\end{array}$ & $\mathbf{x}$ \\
\hline 6. & $\begin{array}{l}\text { Alternatif pemecahan } \\
\text { masalah } \\
\text { dipertimbangkan }\end{array}$ & $\mathbf{x}$ & $\mathbf{x}$ \\
\hline
\end{tabular}

Dari Tabel 6 di atas dapat dilihat bahwa indikator antisipasi subjek S3 pada masalah nomor 1 dan nomor 2 cenderung sama. Subjek S3 secara spontan melakukan penyelesaian dan melakukan aktivitas lain saat membaca. Subjek S3 menduga jawaban dan membuat langkahlangkah pemecahannya. Subjek S3 tidak memikirkan alternatif lain dan tidak mengevaluasi kembali pemecahan masalahnya. Berdasarkan beberapa indikator tersebut dapat disimpulkan bahwa dalam memecahkan masalah aljabar antisipasi yang dominan dari subjek S3 adalah antisipasi kaku.

\section{Pembahasan}

Berdasarkan analisis data yang telah diuraikan sebelumnya terdapat perbedaan karakteristik antisipasi dari ketiga subjek terpilih. Pembahasan antisipasi siswa dalam 
memecahkan masalah aljabar setiap subjek adalah sebagai berikut:

Antisipasi Siswa dalam Memecahkan Masalah Aljabar pada Subjek yang Mempunyai Kecerdasan Linguistik Tinggi dan Kecerdasan Logis-Matematis Tinggi

Diketahui dari uraian analisis data sebelumnya diketahui bahwa subjek S1 dalam memecahkan masalah aljabar menggunakan antisipasi eksploratif. Subjek S1 melakukan penyelesaian secara tidak spontan yaitu membaca soal lebih dari satu kali dan melakukan aktivitas lain untuk memahaminya. Subjek S1 menggabungkan beberapa konsep yang sesuai dengan masalah. Subjek S1 mempertimbangkan alternatif pemecahan dan mengevaluasi kembali pemecahan masalah tersebut. Berdasarkan uraian di atas dapat disimpulkan bahwa subjek yang memiliki kecerdasan linguistik tinggi dan kecerdasan logis-matematis tinggi mampu memahami masalah dan merencanakan pemecahannya dengan baik. Dia juga mengutarakan pendapatnya dengan jelas secara lisan maupun tulisan. Hal ini sesuai dengan penelitian oleh Mega Teguh Budiarto dan Darmawanti yang mendapatkan hasil subjek yang memiliki kecerdasan linguistik tinggi lancar dalam memahami masalah dan menyampaikan pendapatnya. Subjek yang memiliki kecerdasan logismatematis tinggi dapat menjelaskan jawaban secara logis. (Budiarto, 2016)

Antisipasi Siswa Dalam Memecahkan Masalah Aljabar Pada Subjek Yang Mempunyai Kecerdasan Linguistik Tinggi Dan Kecerdasan Logis-Matematis Rendah

Berdasarkan uraian analisis data sebelumnya diperoleh bahwa subjek S2 dalam memecahkan masalah aljabar menggunakan antisipasi analitik. Subjek S2 tersebut membaca soal berulang kali atau tidak spontan dalam memahaminya. Melakukan aktivitas lain berupa menggaris bawahi dan melingkari kata yang dibaca. Membuat dugaan dan langkah pemecahannya serta membayangkan sebabakibat dari masalah tersebut. Mampu mengutarakan pendapatnya dengan baik namun kesulitan dalam menghitung secara sistematis. Subjek S2 juga mempertimbangkan adanya alternatif pemecahan lain pada masalah tersebut.

Kesimpulan dari uraian di atas adalah subjek yang memiliki kecerdasan linguistik tinggi dan kecerdasan logismatematis rendah mampu memahami masalah namun tidak bisa menyelasaikannya dengan baik. Dia mengutarakan pendapat dengan jelas dan lancar. Dia membayangkan dan memperkirakan jawaban berdasarkan informasi yang dipahami. Atau dalam kata lain dia tidak dapat menjelaskan cara maupun hasil pemecahannya secara logis.
Antisipasi Siswa dalam Memecahkan Masalah Aljabar pada Subjek yang Mempunyai Kecerdasan Linguistik Rendah dan Kecerdasan Logis-Matematis Tinggi

Berdasarkan uraian analisis data sebelumnya diperoleh bahwa subjek S3 dalam memecahkan masalah aljabar menggunakan antisipasi kaku. Subjek S3 secara spontan melakukan penyelesaian. Membuat dugaan dan langkahlangkah pemecahannya dalam pikirannya serta langsung menuliskannya. Subjek S3 tersebut tidak memikirkan alternatif lain meskipun dia yakin itu ada. Dia mengabaikan informasi baru dan tidak mengevaluasi kembali pemecahan masalahnya. Sehingga dapat disimpulkan bahwa subjek yang mempunyai kecerdasan linguistik rendah dan logismatematis tinggi dapat memahami dan menyelesaikan masalah dengan baik. Dia dapat merencanakan dugaan dan langkah pemecahan masalahnya. Akan tetapi dia tidak dapat mengutarakan pendapat atau apa yang dipikirkan dengan baik. Meskipun demikian dia tidak terhambat dalam menyelesaikan masalah aljabar tersebut secara logis.

\section{PENUTUP}

\section{Simpulan}

Berdasarkan hasil penelitian dan pembahasan maka dapat dibuat kesimpulan pada penelitian ini sebagai berikut:

1. Antisipasi siswa yang mempunyai kecerdasan linguistik tinggi dan kecerdasan logis-matematis tinggi dalam memecahkan masalah aljabar adalah antisipasi eksploratif. Siswa melakukan penyelesaian masalah secara tidak spontan. Saat membaca masalah, siswa melakukan aktivitas lain. Siswa menggabungkan beberapa konsep tentang masalah. Siswa melakukan pemecahan masalah sesuai dugaan dan mengevaluasinya kembali.

2. Antisipasi siswa yang mempunyai kecerdasan linguistik tinggi dan kecerdasan logis-matematis rendah dalam memecahkan masalah aljabar adalah antisipasi analitik. Siswa melakukan pemecahan masalah secara tidak spontan. Saat membaca masalah, siswa melakukan aktivitas lain yaitu mengaris bawahi dan melingkari. Siswa membuat dugaan jawaban dan langkah-langkah pemecahan masalah. Siswa mempertimbangkan alternatif pemecahan lain dan mengevaluasi kembali pemecahan masalahnya.

3. Antisipasi siswa yang mempunyai kecerdasan linguistik rendah dan kecerdasan logis-matematis tinggi dalam memecahkan masalah aljabar adalah antisipasi kaku. Siswa melakukan aktivitas lain yaitu menggaris bawahi kata yang dibaca. Siswa malakukan pemecahan masalah sesuai dugaan. Siswa tidak mempertimbangkan alternatif pemecahan lain. Siswa mengabaikan informasi baru yang relevan dengan masalah. Siswa tidak mengevaluasi kembali pemecahan masalahnya. 


\section{Saran}

Berikut adalah beberapa saran yang bisa dituliskan oleh penulis:

1. Guru matematika perlu memahami bahwa karakteristik antisipasi siswa dalam memecahkan masalah itu berbeda. Diharapkan dapat memberi perlakuan berupa pembentukan kelompok yang heterogen, pembuatan LKS terbimbing, model pembelajaran diskusi kelas dan lain sebagainya. Sehingga dapat meningkatkan kemampuan pemecahan masalah pada tiap individu siswa.

2. Ditinjau dari kecerdasan linguistik dan kecerdasan logis-matematis siswa memiliki karakteristik antisipasi yang berbeda. Sehingga cara memahami masalah, merencanakan masalah, melaksanakan masalah, dan mengevaluasi pemecahan masalahnya pun berbeda. Maka dalam memberikan tes, masalah harus mempunyai komposisi dan bobot yang sesuai untuk mengukur kemampuan tiap individu siswa.

3. Bagi peneliti lain yang berminat untuk melakukan penelitian serupa dapat menggunakan masalah lain misalnya: statistika, geometri dan atau yang lainnya. Peneliti lain juga bisa menggunakan peninjau lain selain kecerdasan majemuk, misalnya kriteria kepribadian, gaya kognitif, atau kemampuan komunikasi.

\section{DAFTAR PUSTAKA}

Budiarto, Mega Teguh dan Darmawanti Fitria Febriana. 2016. "Profil Berpikir Kreatif Siswa Smp Berkecerdasan Linguistik, Logis-matematis, Dan Visual-Spasial Dalam Menyelesaikan Masalah Persegipanjang”. Jurnal Ilmiah Pendidikan Matematika, Vol. 2.

Hudojo, Herman. 2003. Pengembangan Kurikulum dan Pembelajaran Matematika. Malang: UM Press.

Lim, K. 2006. “Characterizing students' thinking: Algebraic inequalities and equations". Group for the Psychology of Mathematics Education. Vol. 2, pp. 102-109.

Lim, K. 2007. “Improving Students' Algebraic Thinking: The Case of Talia". Proceedings of the 31st Conference of the international Group for the Psychology of Mathematics Education, Vol. 3, pp.193200.

Polya, G. 1973. How to Solve It: A New Aspect of mathematical Method. New Jersey: Princeton University Press.

Yaumi, Muhammad. 2012. Pembelajaran Berbasis Multiple Intelligences. Jakarta: PT. Dian Rakyat 